\title{
The Physiology of Mould-Yeast Dimorphism in the Genus Mycotypha (Mucorales)
}

\author{
By M. J. HALL* AND N. KOLANKAYA \\ Institute of Biology, Hacettepe University, Ankara, Turkey
}

(Received I2 July 1973; revised 26 October 1973)

\begin{abstract}
SUMMARY
Mycotypha africana and four strains of Mycotypha microspora were studied. The former displayed total conversion from mycelium $(M)$ to yeast $(\mathrm{Y})$ when grown under $\mathrm{N}_{2}$ or in the presence of some electron-transport inhibitors with either glucose, fructose or mannose as carbon source. In air, mixed filamentous and yeast-like forms were frequently observed. Acid $\mathrm{pH}$, high temperature, dense inoculum and high hexose level increased the proportion of the $Y$-form. Yeast and mycelial phases were interconvertible. All but one strains of $M$. microspora tested displayed similar dimorphism, but strain to strain variations were observed.
\end{abstract}

\section{INTRODUCTION}

Mould-yeast (MY) dimorphism has been investigated in a number of pathogenic and non-pathogenic fungi from a wide range of taxonomic groups (see reviews of Romano, I966, and Bartnicki-García, I968a). Physiological control of this phenomenon varies between organisms; temperature, medium composition and nature of the gas-phase have all been implicated.

In the Mucorales, only the genus Mucor has been reported to display MY dimorphism (Bartnicki-García \& Nickerson, 1962a). The major determining factors were the gas-phase and hexose sugar concentration (Bartnicki-García, I968b). Yeast-like growth occurred under $\mathrm{CO}_{2}$ and a mycelium under $\mathrm{N}_{2}$ or air. These growth patterns were constant for Mucor rouxii over a wide range of physical and nutritional conditions but induction of the Y-phase by $\mathrm{CO}_{2}$ could be reversed by EDTA or other $\mathrm{N}$-acetic acid type chelating agents (Bartnicki-García \& Nickerson, 1962 b). Mucor subtilissimus grew as a yeast under both $\mathrm{N}_{2}$ and $\mathrm{CO}_{2}$. Hence, the existence of an EDTA-sensitive inducer of the Y-phase was postulated, the synthesis of which required $\mathrm{CO}_{2}$ in $M$. rouxii but not in $M$. subtilissimus, and which was thought to act on the wall polymers responsible for maintaining cell shape. A'greatly increased mannose content in the Y-phase wall (probably present as a mannose-polysaccharide) supported this suggestion (Bartnicki-García \& Nickerson, 1962c).

More recently Terenzi \& Storck (I968) showed that $0.2 \%(\mathrm{v} / \mathrm{v})$ of $\beta$-phenylethyl alcohol (PEA) also induced the Y-phase, inhibited the expression of cytochrome oxidase activity and stimulated alcoholic fermentation in Mucor rouxii, provided that $2 \%$ or more of a hexose was provided in the medium.

In the present communication the factors controlling dimorphism in another genus of the Mucorales, namely Mycotypha, which was recently placed in the family Thamnidiaceae (Young, 1969), are described.

\footnotetext{
* Present address: Research Division, Roche Products Ltd, Welwyn Garden City, Hertfordshire AL7 3AY.
} 


\section{METHODS}

Organisms. Mycotypha africana (CBSI22.64) and four strains of Mycotypha microspora, namely CBSI86.68, IMII0862 I, IMI3I 239 and an isolate from Madras soil, designated here as M. microspora, Subramanian strain, were studied. Slopes grown on Sabouraud-maltose agar at $30^{\circ} \mathrm{C}$ and stored at $4{ }^{\circ} \mathrm{C}$ were used up to 6 weeks old, after which spore viability markedly decreased. In some experiments, Mucor rouxii was used for comparison.

Media and chemicals. The medium (YPG) of Bartnicki-García \& Nickerson (I962a) was used. The composition (g/l) was: yeast extract (Difco), 3.0; peptone (Fisher Scientific), I0.0; glucose, 20.0. Solid medium contained, in addition, $15 \mathrm{~g}$ agar (Fisher)/1. Variations in glucose concentration are indicated by a number following the letters YPG, e.g. YPG-50 means basal medium with $50 \mathrm{~g}$ glucose/l. Unless otherwise stated, all media were adjusted to pH 5 with $\mathrm{H}_{2} \mathrm{SO}_{4}$, dispensed in $50 \mathrm{ml}$ portions in $250 \mathrm{ml}$ Erlenmeyer flasks and autoclaved at $\mathrm{I} 2 \mathrm{I}{ }^{\circ} \mathrm{C}$ for $\mathrm{I} 5 \mathrm{~min}$. In experiments in which $\mathrm{pH}$ and nature or concentration of carbon source were varied, the carbohydrates were autoclaved separately at $115{ }^{\circ} \mathrm{C}$ for $10 \mathrm{~min}$. Aqueous solutions of $\mathrm{KCN}$, cysteine, tryptophol ( $3 \beta$-hydroxyethyl-indole) and the disodium salt of EDTA were sterilized by membrane filtration (Millipore Ltd, Type HA, $0.45 \mu \mathrm{m}$ ). B-phenylethylalcohol (Fluka Chemical Co., Burchs, Switzerland) was added directly without sterilization. Antimycin A (Sigma), oligomycin(Sigma) and 2-thienoyltrifluoroacetone (TTFA, Fluka Chemical Co.) were added as ethanolic solutions. Rotenone (Sigma) was first dissolved in benzene and then appropriately diluted into ethanol. The solvents alone were without effect. All chemicals were of analytical grade and distilled water was employed throughout.

Submerged cultivation. Spores were used either directly or after pre-germination. For pregermination, a $10 \mathrm{ml}$ suspension was transferred to $50 \mathrm{ml}$ YPG broth in static culture at $30{ }^{\circ} \mathrm{C}$ for $8 \mathrm{~h}$, during which time 60 to $70 \%$ of the spores swelled to spheres. The medium was centrifuged, the pellet resuspended in $10 \mathrm{ml}$ of YPG broth and the spores counted in a haemocytometer. The inoculum was adjusted to give $500000 \mathrm{spores} / \mathrm{ml}$ of culture broth. Incubation, unless otherwise stated, was at $35^{\circ} \mathrm{C}$ and $\mathrm{I} 75 \mathrm{rev} . / \mathrm{min}$ in a Metabolite water bath shaker (New Brunswick) with a circular throw of $\mathrm{I} \cdot 27 \mathrm{~cm}$ diam. To separate the growth forms the mixture of $\mathrm{M}$ and $\mathrm{Y}$ was filtered through cheese cloth. The mycelial pad was then resuspended in water and refiltered. This procedure was repeated three times. The two phases were then separately filtered through pre-dried, pre-weighed filter-paper discs and dried to constant weight at $50{ }^{\circ} \mathrm{C}$.

Control of the gas phase. Oxygen-free $\mathrm{N}_{2}$ and $\mathrm{CO}_{2}$ were used. Gasses were mixed to the desired percentage composition by means of pre-calibrated microflowmeters. Accuracy of composition was verified by testing samples with an Orsat Gas Analyser (Elsworth, 1970). Gas was passed from flask to flask and flow rate adjusted to 2 to 3 bubbles/s by using a gas bleed on the supply line (Bartnicki-García \& Nickerson, 1962a). To purge air from the system, media were incubated for $2 \mathrm{~h}$ at a high gas-flow rate before inoculation.

Growth on solid media. Solid YPG medium in $9 \mathrm{~cm}$ Petri dishes was transferred immediately after inoculation to a desiccator which was evacuated and refilled with $\mathrm{N}_{2}$ or $\mathrm{CO}_{2}$. This procedure was repeated five times to ensure removal of all oxygen. When $\mathrm{N}_{2}$ was used the desiccator also contained a beaker of $20 \% \mathrm{KOH}$ to absorb metabolic $\mathrm{CO}_{2}$.

Observations on individual spores. YPG medium containing spores was introduced into a sterile haemocytometer slide (density about 100 spores/grid) and the edges of the cover glass sealed with wax. The squares of the grid were numerically coded and the position and shape 
of the spores noted. The haemocytometer was incubated in a $\mathrm{N}_{2}$-filled moist chamber. The spores were subsequently located and observed for swelling and budding.

\section{RESULTS}

The words 'yeast phase' and 'yeast' are used to describe the yeast-like morphology only when multipolar budding cells were observed. Swollen spores, which often deposited wall material and produced gas but failed to bud, are referred to as 'swollen spores'.

Microscopic examination failed to detect arthrospore formation in any experiment, the Y-phase cells arising directly from spores without an intermediate mycelial phase.

\section{Studies with Mycotypha africana}

Effect of $\mathrm{pH}$ and incubation temperature. YPG medium at initial $\mathrm{pH}$ values of from 2 to 9 was incubated at temperatures from 25 to $37^{\circ} \mathrm{C}$. The organism grew between $\mathrm{pH} 3$ and $7 \cdot 5$, and at all temperatures tested. Stimulation of Y-phase formation was evident at higher temperatures and at lower $\mathrm{pH}$ values. The effects were slightly additive and maximum $\mathrm{Y}$ phase (about $15 \%$ ) was produced at $\mathrm{pH} 4.5$ and $37^{\circ} \mathrm{C}$.

Effect of variation in culture medium and inoculum level. Varying the glucose concentration in YPG medium from 0.5 to $100 \mathrm{~g} / 1$ (Table $\mathrm{I}$ ) indicated that total growth was depressed at levels above $40 \mathrm{~g} / \mathrm{l}$ and that the proportion of $\mathrm{Y}$-phase rose with increased carbohydrate up to $50 \mathrm{~g} / 1$, after which it declined. At higher carbohydrate levels an inoculum effect became apparent. Thus at $20 \mathrm{~g} / \mathrm{l}$, inocula of $9 \times 10^{5}, 10^{5}$ and $2 \times 10^{4}$ spores $/ \mathrm{ml}$ culture broth resulted in $19 . \mathrm{I}, 14.8$ and $3.4 \% \mathrm{Y}$-phase respectively. As the sugar level rose the inoculum effect became more marked and at $50 \mathrm{~g} / 1$ the $\mathrm{Y}$-phase reached 50 to $60 \%$ of the total.

The nature of the carbon source had no influence on MY dimorphism of Mycotypha africana growing in air (Table 2). Growth of both $\mathrm{Y}$ - and M-phases was most abundant on hexose sugars while some pentoses failed to support growth. Morphology was unaffected by variations in the type or concentration of peptone employed.

Effect of the gas phase. Mucor rouxii behaved in the manner described by BartnickiGarcia \& Nickerson (1962b) and produced a sparse mycelium under $\mathrm{N}_{2}$ and spherical budding cells under $\mathrm{CO}_{2}$. By contrast, Mycotypha africana grew as the Y-phase under $\mathrm{N}_{2}$ and produced thin-walled swollen spores under $\mathrm{CO}_{2}$ (Fig. I ; Table 3). Extensive examination of the latter failed to detect budding and no increase in cell number was detectable by haemocytometer counting, indicating that proliferation was absent. These morphological forms were unaffected by changes in $\mathrm{pH}$ or temperature but were influenced by the nature of the carbon source as shown in Table 2. Similar forms were observed in solid YPG medium. It was noteworthy that upon removal from the $\mathrm{CO}_{2}$ or $\mathrm{N}_{2}$ into air, the Mucor plates failed to produce sporangiophores (Bartnicki-García \& Nickerson, $1962 b$ ) in contrast with Mycotypha which developed small though otherwise normal sporangiophores in 24 to $36 \mathrm{~h}$.

The data above suggested that low oxygen tension induced the Y-phase. This was further supported by experiments in which Mycotypha africana was grown in $\mathrm{N}_{2} / \mathrm{O}_{2}$ mixtures at different oxygen partial pressures (Fig. 2). With agitation at $150 \mathrm{rev} . / \mathrm{min}$ the Y-phase predominated up to an oxygen partial pressure of 0.10 to 0.1 I. Increased agitation (I75 rev./ min) decreased the oxygen partial pressure at which the transition from $\mathbf{Y}$ to $\mathbf{M}$ occurred.

Effect of inhibitors of the cytochrome system. The addition of $\mathrm{KCN}\left(\mathrm{IO}^{-3} \mathrm{M}\right)$ to cultures of Mycotypha africana growing in YPG-10 medium in air induced almost $100 \%$ Y-phase. At lower concentrations of $\mathrm{KCN}, \mathrm{Y}$ formation was enhanced but to a lesser degree (Table 4). Similarly, $0.4 \mu \mathrm{g}$ oligomycin $/ \mathrm{ml}$ and $0.2 \mu \mathrm{g}$ antimycin $\mathrm{A} / \mathrm{ml}$ induced $100 \% \mathrm{Y}$-phase. 
Table I. Effect of glucose concentration and $\beta$-phenylethyl alcohol (PEA) on growth and morphology of Mycotypha africana under air

\begin{tabular}{|c|c|c|c|c|}
\hline \multirow{2}{*}{$\begin{array}{l}\text { Glucose } \\
\text { concentration } \\
(\mathrm{g} / \mathrm{l})\end{array}$} & \multicolumn{2}{|c|}{ No. PEA } & \multicolumn{2}{|c|}{$0.2 \%(v / v)$ PEA } \\
\hline & $\begin{array}{l}\text { Total growth* } \\
\text { (mg dry wt/50 ml) }\end{array}$ & $\begin{array}{l}\text { Yeast } \\
(\%)\end{array}$ & $\begin{array}{c}\text { Total growth } \ddagger \\
\text { (mg dry wt } / 50 \mathrm{ml} \text { ) }\end{array}$ & $\begin{array}{l}\text { Yeast } \\
(\%)\end{array}$ \\
\hline 0 & $70(62-92)$ & 0 & $40(33-46)$ & 0 \\
\hline 0.5 & $140(129-147) \dagger$ & 0 & N.T. & N.T. \\
\hline 5.0 & $173(\mathrm{I} 64-18 \mathrm{I})$ & 0 & $142(13 I-15 I)$ & I $(0-3)$ \\
\hline $10 \cdot 0$ & $256(231-289)$ & $(0-9)$ & $145(136-151)$ & $90(87-96)$ \\
\hline 20.0 & $304(292-320)$ & $(3-25)$ & $135(130-138)$ & $82(76-90)$ \\
\hline $30 \cdot 0$ & $272(256-288)$ & $(16-30)$ & I30 (122-136) & $96(94-100)$ \\
\hline 40.0 & $291(260-316)$ & $(28-6 I)$ & $105(96-114)$ & $76(69-80)$ \\
\hline $50 \cdot 0$ & $263(239-28 \mathrm{I})$ & $62 \quad(27-65)$ & $75(66-87)$ & $60(54-69)$ \\
\hline $100 \cdot 0$ & $204(184-215) \dagger$ & $3 I \cdot 5(13-56)$ & N.T. & N.T. \\
\hline & & N.T. $=$ not te & & \\
\hline
\end{tabular}

* Figures in this column represent average data from four experiments each with three replicates.

$\dagger$ Only two experiments were conducted.

¥ Average data from two experiments each with three replicates.

Table 2. Effect of carbon source and gas phase on the growth and morphology of Mycotypha africana and three strains of Mycotypha microspora

Figures represent $\mathrm{mg}$ dry $\mathrm{wt} / 50 \mathrm{ml}$.

\begin{tabular}{|c|c|c|c|c|c|c|}
\hline \multirow{2}{*}{$\begin{array}{l}\text { Carbon* } \\
\text { source }\end{array}$} & \multicolumn{3}{|c|}{ Mycotypha africana under: } & \multicolumn{3}{|c|}{ Strains of Mycotypha microspora under $\mathrm{N}$} \\
\hline & Air & $\mathrm{CO}_{2}$ & $\mathrm{~N}_{2}$ & I0862 I & 186.68 & 31239 \\
\hline Glucose & $255(\mathrm{M})$ & 85 (SS) & $127(Y)$ & $90(\mathrm{Y})$ & $50(\mathrm{Y})$ & I0 (M) \\
\hline Fructose & $305(\mathrm{M})$ & 85 (SS) & $129(\mathrm{Y})$ & $99(\mathrm{Y})$ & $44(\mathrm{Y})$ & IO (M) \\
\hline Galactose & $245(\mathrm{M})$ & 35 (SS) & I8 (SS) & $37(\mathrm{Y} / \mathrm{M})$ & $30(Y)$ & $8(\mathrm{M})$ \\
\hline Mannose & $270(\mathrm{M})$ & $40(Y)$ & $138(Y)$ & $76(Y)$ & $52(Y)$ & $34(\mathrm{M} / \mathrm{Y})$ \\
\hline Sucrose & $205(\mathrm{M})$ & 15 (SS) & 87 (SS) & $23(\mathrm{Y})$ & $9(\mathrm{Y})$ & $6(\mathrm{M} / \mathrm{SS})$ \\
\hline Maltose & $205(\mathrm{M})$ & II (SS) & 21 (SS) & N.T. & N.T. & N.T. \\
\hline None & $145(\mathrm{M})$ & N.G. & N.G. & N.G. & N.G. & N.G. \\
\hline
\end{tabular}

Lactose, D-xylose, D-arabinose, mannitol, citrate and starch failed to support growth of $M$. africana or $M$. microspora under $\mathrm{CO}_{2}$ or $\mathrm{N}_{2}$. Under air, growth of $M$. africana was similar to that with no added C source. N.G. $=$ no growth; N.T. $=$ not tested.

$\mathrm{M}=$ mycelial phase; $\mathrm{Y}=$ yeast-phase; $\mathrm{SS}=$ swollen spores.

* All tested at a concentration of $20 \mathrm{~g} / \mathrm{l}$.

Experiments with TTFA were more variable and at the highest non-toxic concentration tested $\left(\mathrm{IO}^{-4} \mathrm{M}\right)$ conversion varied from 34 to $88 \%$. PEA differed in exhibiting its Y-inducing effect only in the presence of $1 \%$ or more glucose (Table 1). Amytal and rotenone were inactive up to $5 \times 10^{-3} \mathrm{M}$, although distorted filamentous forms were often produced.

Effect of EDTA, cysteine and tryptophol. The effect of EDTA on Mycotypha africana was tested by using either spores or pre-germinated spores as inoculum, with essentially the same results. Low concentrations $\left(5 \times 10^{-6} \mathrm{M}\right)$ stimulated growth of both phases by 10 to $14 \%$. Above this, growth was decreased to a point of complete inhibition at $5 \times 10^{-4} \mathrm{M}$. Under a $\mathrm{N}_{2}$ gas phase the cells at $5 \times 10^{-5} \mathrm{M}$ were enlarged (mean diameter $46 \cdot \mathrm{I} \mu \mathrm{m}$, compared with $30.6 \mu \mathrm{m}$ normally) but still exhibited multipolar budding, while at $10^{-4} \mathrm{M}$ budding was completely inhibited and most cells had rudimentary hyphae 100 to I50 $\mu \mathrm{m}$ long.

Tryptophol slightly stimulated production of the Y-phase but cysteine was without effect on MY dimorphism. 

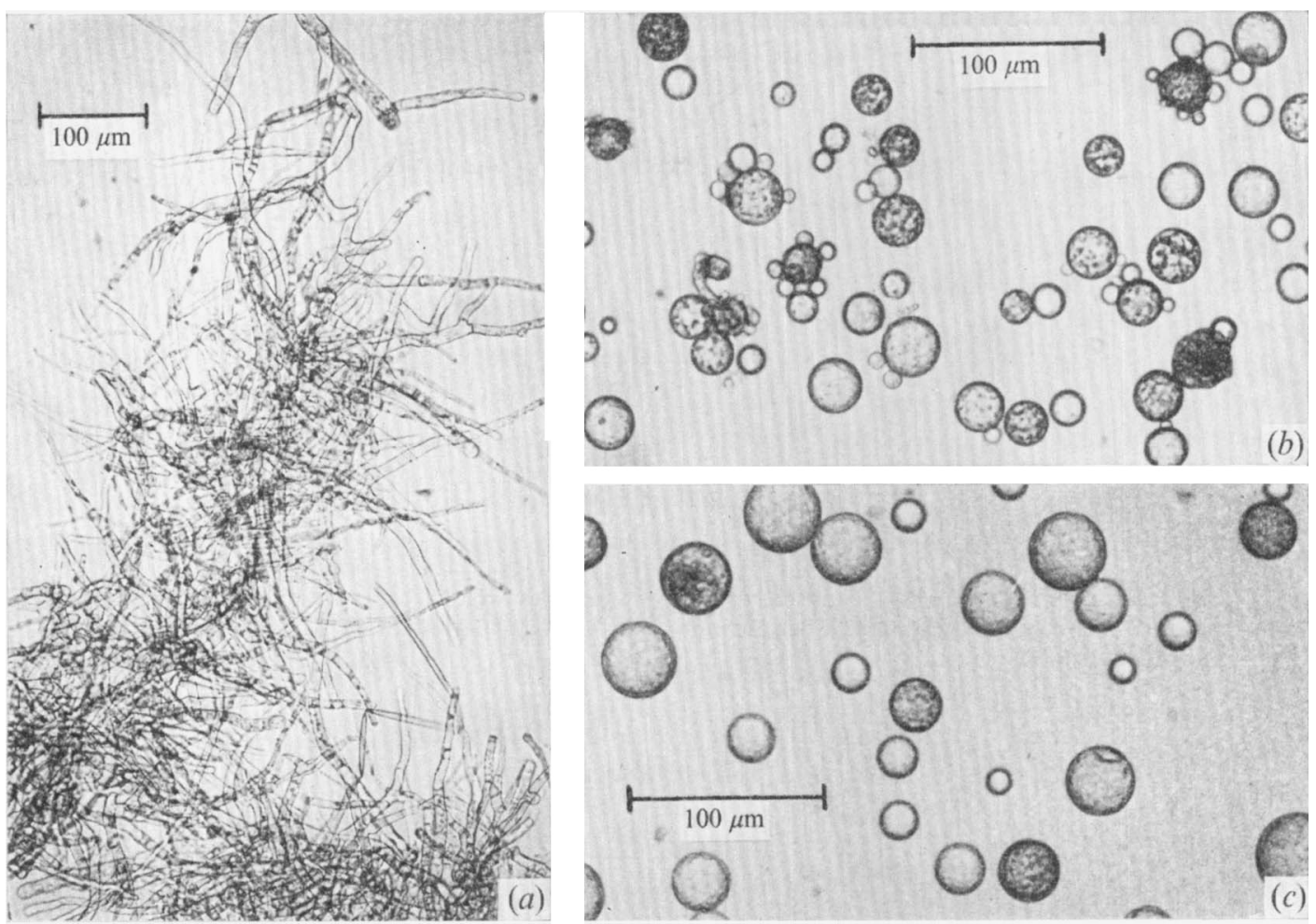

Fig. I. Morphological forms of $M$. africana grown under different atmospheres in YPG medium for 48 h. (a) Typical mycelial development in air; (b) Y-phase cells under $\mathrm{N}_{2}$ exhibiting multipolar budding; $(c)$ swollen spores under $\mathrm{CO}_{2}$.

Table 3. Comparison of the growth and dimorphism of $M$. africana and Mucor rouxii in $Y P G$ medium at $30^{\circ} \mathrm{C}$ under $\mathrm{N}_{2}, \mathrm{CO}_{2}$ and air

\begin{tabular}{|c|c|c|c|c|c|c|}
\hline \multirow[b]{2}{*}{$\begin{array}{c}\text { Gas } \\
\text { phase }\end{array}$} & \multicolumn{3}{|c|}{ M. africana } & \multicolumn{3}{|c|}{ Mucor rouxii } \\
\hline & $\begin{array}{c}\text { Dominant } \\
\text { morphology }\end{array}$ & $\begin{array}{c}\text { \% as } \\
\text { mycelial } \\
\text { phase }\end{array}$ & $\begin{array}{l}\text { Total dry } \\
\text { weight } \\
\text { (mg/50 ml) }\end{array}$ & $\begin{array}{l}\text { Dominant } \\
\text { morphology }\end{array}$ & $\begin{array}{c}\% \text { as } \\
\text { mycelial } \\
\text { phase }\end{array}$ & $\begin{array}{l}\text { Total dry } \\
\text { weight } \\
(\mathrm{mg} / 50 \mathrm{ml})\end{array}$ \\
\hline Air & M & 87 & 269 & $\mathbf{M}$ & 99 & 384 \\
\hline $\mathbf{N}_{2}$ & $Y$ & 0 & 112 & $\mathbf{M}$ & 96 & 35 \\
\hline $\mathrm{CO}_{2}$ & SS & 0 & 48 & $\mathbf{Y}$ & 0 & 77 \\
\hline
\end{tabular}

$\mathrm{M}=$ mycelium; $\mathrm{Y}=$ yeast-phase; $\mathrm{SS}=$ swollen spores (no budding).

The relationship of spore and vegetative dimorphism. A total of 730 individual spores were observed for $\mathrm{I} 20 \mathrm{~h}$, comprising $2 \mathrm{I} 6$ more or less spherical ( $2 \cdot 8$ to $3 \cdot 2 \mu \mathrm{m}$ dia), 294 oval/elliptical (3.3 to $5.3 \mu \mathrm{m}$ long) and 220 which were more or less rectangular in profile $(5.4$ to $6.2 \mu \mathrm{m}$ long). After 24 to $36 \mathrm{~h}, 90 \%$ of the oval and rectangular groups and $75 \%$ of the spherical spores had swollen to spheres. Between 36 and $50 \mathrm{~h}, 7$ rectangular, 6 oval/elliptical and 2 spherical spores developed small bud initials. No further development took place under these conditions. Attempts to separate the spore types by centrifugation and filtration were unsuccessful. However, it seemed likely that all spore types could develop into the Y-phase, and that spore dimorphism (Young, 1969) was not related to vegetative development. 


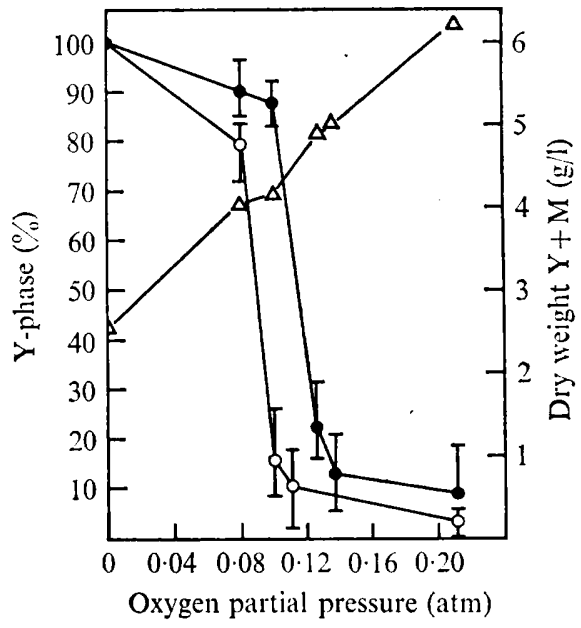

Fig. 2. Effect of oxygen partial pressure in $\mathrm{N}_{2} / \mathrm{O}_{2}$ gas mixtures on the total growth and development of the Y-phase of $M$. africana in YPG medium at $30^{\circ} \mathrm{C} . \triangle$, total growth;,$\% \mathrm{Y}$ at $150 \mathrm{rev} . / \mathrm{min}$; $0, \% \mathrm{Y}$ at $\mathrm{I} 75 \mathrm{rev} . / \mathrm{min}$.

Table 4. Effect of KCN on the growth and morphology of Mycotypha strains in YPG-Io medium at $25^{\circ} \mathrm{C}$

\begin{tabular}{|c|c|c|c|c|c|c|}
\hline \multirow[b]{3}{*}{ Organism } & \multicolumn{6}{|c|}{$\mathrm{KCN}$ concentration } \\
\hline & \multicolumn{2}{|c|}{ Zero } & \multicolumn{2}{|c|}{$10^{-4} \mathrm{M}$} & \multicolumn{2}{|c|}{$10^{-3} \mathrm{M}$} \\
\hline & $\begin{array}{c}\text { Total } \\
\text { growth } \\
(\mathrm{mg} / 50 \mathrm{ml})\end{array}$ & $\begin{array}{c}\text { Yeast } \\
(\%)\end{array}$ & $\begin{array}{c}\text { Total } \\
\text { growth } \\
(\mathrm{mg} / 50 \mathrm{ml})\end{array}$ & $\begin{array}{c}\text { Yeast } \\
(\%)\end{array}$ & $\begin{array}{c}\text { Total } \\
\text { growth } \\
(\mathrm{mg} / 50 \mathrm{ml})\end{array}$ & $\begin{array}{c}\text { Yeast } \\
(\%)\end{array}$ \\
\hline M. africana & 215 & $8 \cdot 6$ & 135 & $66 \cdot 6$ & 100 & 90 \\
\hline M. microspora IMII0862I & 210 & 0 & 120 & $17 \cdot 0$ & 50 & 100 \\
\hline M. microspora CBSI 86.68 & 230 & $7 \cdot 3$ & 210 & $3 I \cdot 5$ & 52 & $52 \cdot 2$ \\
\hline M. microspora (Subramanian) & 150 & 0 & IIO & $9 \cdot 0$ & 75 & 55 \\
\hline M. microspora IMI31239 & 200 & 0 & 240 & 0 & 0 & 0 \\
\hline
\end{tabular}

Interconvertibility of $Y$ - and $M$-phases. By transferring a small $(0 \cdot \mathrm{I} \mathrm{ml})$ inoculum to fresh YPG medium under $\mathrm{N}_{2}$ every $48 \mathrm{~h}$, Mycotypha africana was maintained growing as the $\mathrm{Y}$ phase for 30 days, with no change in morphological form. Such Y-cells reverted to a mycelium within 6 to $8 \mathrm{~h}$ of transfer to air, indicating that the capacity for mycelial development was not lost. Conversely, when young mycelium (up to $8 \mathrm{~h}$ after germ-tube formation) was transferred to a $\mathrm{N}_{2}$ atmosphere, the cells became swollen and began budding to form a Y phase (Fig. 3a). Older mycelium failed to develop and became darkly pigmented. The Yphase of Mycotypha microspora did not grow for more than two or three passages, probably because of the formation of many thick-walled cells susceptible to osmotic lysis upon transfer (Fig. $4 b$ ).

\section{Studies with Mycotypha microspora}

Although some strain to strain variation was observed, MY dimorphism in IMII0862I, CBSI86.68 and the Subramanian strain was essentially similar to Mycotypha africana. However, triangular and stellate cells were produced in many experiments, preventing accurate quantification of the growth forms. Strain IMI3 239 formed a few Y-cells in only one experiment and lacked the morphological flexibility of the other strains. 

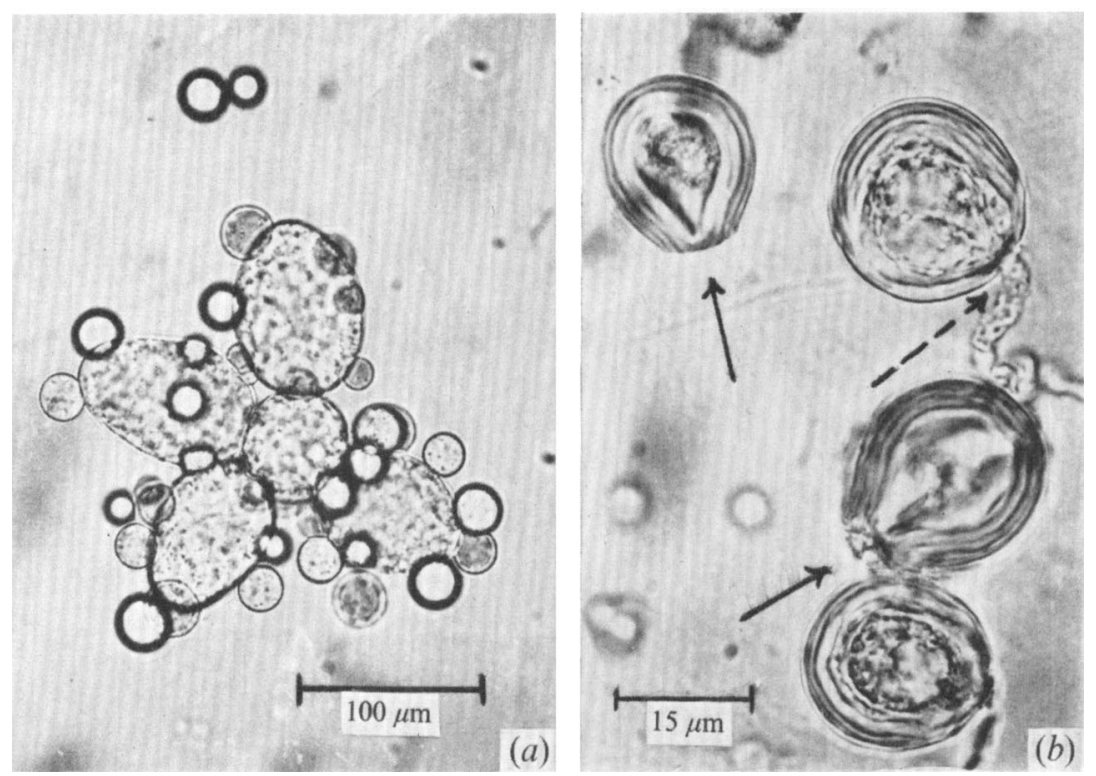

Fig. 3. (a) Reversion of a young mycelium of Mycotypha africana to budding Y-phase after transfer from air to $\mathrm{N}_{2}$. The original central cell and four germ tubes have swollen and commenced budding. (b) Y-phase of Mycotypha microspora CBSI 86.68 grown in the presence of $5 \times 10^{-4} \mathrm{M} \mathrm{KCN}$. The cells display heavily thickened walls. One cell (broken arrow) is in the process of discharging its protoplast and two others (solid arrows) are empty.

Effect of medium composition and incubation conditions in air. The effects of temperature, $\mathrm{pH}$ and $\mathrm{C}$ source were generally similar to those described for Mycotypha africana. All strains of Mycotypha microspora resembled Mycotypha africana in displaying maximum dry weight at $20 \mathrm{~g}$ glucose/1. Strain IMII0862 I produced mixed mycelium and budding yeast at high ( $100 \mathrm{~g} / \mathrm{l}$ ) glucose but mycelium alone at low ( $\mathrm{I} 0 \mathrm{~g} / \mathrm{l}$ ) concentrations. With CBSI 86.68, the Subramanian strain and IMI3I239, budding was not detected at any glucose level, though in the first two strains non-budding spherical cells were present at high concentrations of glucose. The spherical cells formed by these two organisms and IMII0862I had heavily thickened walls, the tendency being most marked in CBSI86.68 and IMII08621. Such cells frequently burst, especially on transfer to fresh medium (Fig. $3 b$ ).

Growth under nitrogen and carbon dioxide. With the exception of IMI3I 239, which formed a stunted mycelium (Fig. 4), all strains grew as a Y-form in YPG medium under $\mathrm{N}_{2}$ provided a hexose or sucrose was the $\mathrm{C}$ source (Table 2). Strain IMI3 239 developed as a yeast only on mannose when a few clusters of budding cells were present among the sparse mycelium. Under $\mathrm{CO}_{2}$, development of all strains was inhibited except for partial swelling of a few spores.

Effect of inhibitors of the cytochrome system. All strains of Mycotypha microspora differed in their behaviour. IMII0862 I resembled Mycotypha africana in forming a pure Y-form at ${ }^{10^{-3}} \mathrm{M} \mathrm{KCN}$ (Table 4). The same trend was noted in CBSI86.68 and the Subramanian strain but conversion was only 50 to $60 \%$. IMI3I 239 failed to grow. Lower KCN concentrations ( $10^{-4}$ and $5 \times 10^{-4} \mathrm{M}$ ) had the same general effect, but mixtures of forms were produced depending on the strain employed.

Rotenone, antimycin A and amytal were inactive against all strains except for some growth inhibition. Oligomycin induced the Y-phase only in CBSI86.68, the conversion reaching 

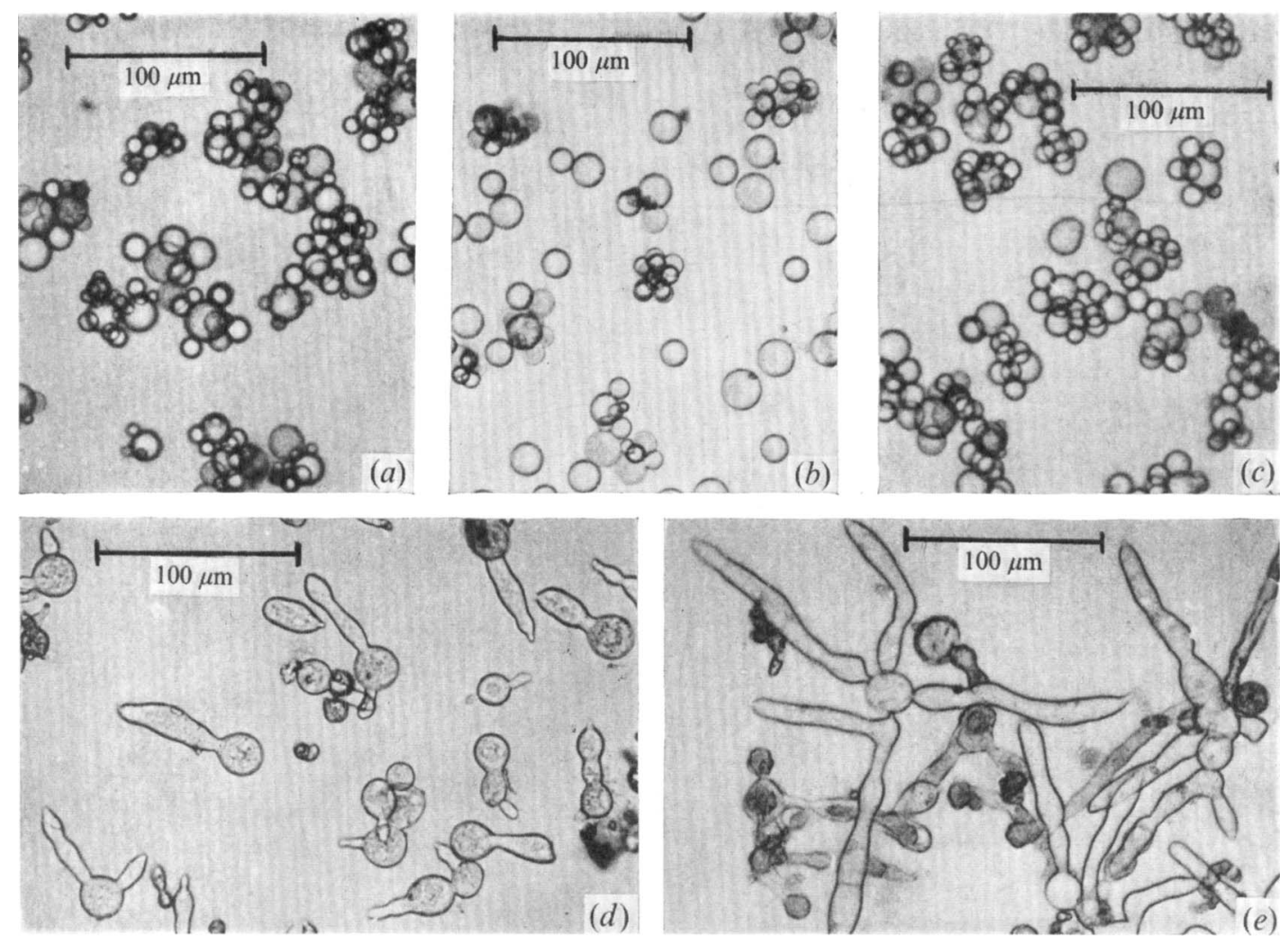

Fig. 4. Growth of four strains of $M$. microspora under $\mathrm{N}_{2}$ in YPG medium. (a) The Subramanian strain $48 \mathrm{~h}$; ; (b) CBSI 86.68, $48 \mathrm{~h} ;(c)$ IMII 0862 I , $48 \mathrm{~h} ;(d)$ IMI3I 239, after $24 \mathrm{~h}$; (e) IMI3I 239, after $48 \mathrm{~h}$.

I $00 \%$ at $4 \mu \mathrm{g} / \mathrm{ml}$, a tenfold higher concentration than was effective with Mycotypha africana. With other strains, this compound significantly reduced the dry weight but did not affect the morphological form. TTFA was active only against the Subramanian strain, where maximum Y-phase $\left(3 \mathrm{I} \%\right.$ ) formed at $5 \times 1 \mathrm{I}^{-5} \mathrm{M}$. Higher concentrations were toxic. PEA induced a mixture of stunted mycelium, yeast and stellate forms in IMII0862I and the Subramanian strain and showed the same glucose dependence as with Mycotypha africana.

\section{DISCUSSION}

Of eight genera of Mucorales tested by Bartnicki-García \& Nickerson (1962 $b$ ), only Mucor displayed MY dimorphism. The present communication establishes that the phenomenon is also a characteristic of the genus Mycotypha.

Control of dimorphism in Mucor rouxii and Mycotypha africana. Extensive studies of Mucor rouxii (Bartnicki-García \& Nickerson, I962a, b, c; Bartnicki-García, I968b; Terenzi \& Storck, I968; Bartnicki-García \& Lipmann, I969, 1972) revealed that partial pressure of $\mathrm{CO}_{2}$ and hexoses were the major factors controlling yeast-phase development. At low hexose or $\mathrm{CO}_{2}$ levels, or both, development was filamentous. At high hexose (above $8 \%$ ) it was in the $\mathrm{Y}$ form, even in air, while at lower levels supplementation of up to $30 \% \mathrm{CO}_{2}$ in the incubation atmosphere was necessary (Bartnicki-García, 1968b). Anaerobic conditions in themselves did not stimulate $\mathrm{Y}$ formation and growth under pure $\mathrm{N}_{2}$ was filamentous. Other nutritional factors were largely without effect. The $\mathrm{CO}_{2}$-induced Y-phase reverted to a filamentous form in the presence of low EDTA concentrations. 
Mucor rouxii and Mycotypha africana responded differently to $\mathrm{N}_{2}$ and $\mathrm{CO}_{2}$ atmospheres (Table 3). Carbon dioxide was not a major factor in MY dimorphism in Mycotypha although enhancement of the Y-phase has been noted in a $\mathrm{N}_{2}$ atmosphere enriched with $4.2 \% \mathrm{CO}_{2}$ (G. Kraepelin and B. Schultz, private communication). Rather, the evidence suggested that anerobiosis, whether induced by control of the gas phase or by inhibitors of electron transport, was the key factor. This was supported by the observation that a faster agitation rate, which would increase the oxygen transfer rate into solution (Finn, 1954) decreased the oxygen partial pressure at which the $M$ to $Y$ transition occurred (Fig. 2).

Similarly, the increased proportion of Y-cells which accompanied increased hexose levels (Table I) could be attributed to $\mathrm{O}_{2}$ depletion of the broth by the more actively growing organism.

The cytochrome inhibitors fell into two categories. Those which blocked electron flow or acted as uncoupling agents ( $\mathrm{KCN}$, oligomycin, antimycin $\mathrm{A})$ produced total conversion to the Y-phase, while those which acted on a specific branch of the electron transport chain (TTFA, rotenone, amytal) were inactive or less absolute in effect. PEA which was known to favour $\mathrm{Y}$ development in Candida albicans (Lingappa et al. 1969) showed a glucosedependent effect on both Mucor rouxii and Mycotypha africana. In $M$. rouxii, it stimulated alcoholic fermentation, possibly through its action as a cytochrome-oxidase inhibitor (Terenzi \& Storck, I968). A similar explanation could apply to $M$. africana, although the effect of PEA on alcoholic fermentation was not determined in this case.

In Mycotypha africana, MY dimorphism was more sensitive to temperature, $\mathrm{pH}$ and inoculum change than in Mucor rouxii though none of the factors were of great individual significance. The effect of EDTA suggested that a common metal ion-dependent enzyme might be involved in yeast formation in both organisms.

Dimorphism in Mycotypha microspora. Strains IMII0862 I, CBSI86.68 and the Subramanian strain resembled Mycotypha africana in their response to $\mathrm{pH}$, temperature, gas phase and requirement for a hexose sugar for Y-cell formation. However, they differed in their general failure to form a Y-phase at high glucose levels (although other morphological effects such as changes in hyphal diameter and degree of branching were evident) and in their response to cytochrome inhibitors (Table 4). In the latter case the abnormally thick walls and restricted intercellular spaces suggested that an oversynthesis and deposition of wall material was occurring (Fig. 3).

The remaining strain, IMI31239, usually failed to display dimorphic behaviour, either producing a mycelium or failing to grow at all (Fig. 4, Table 4). Only under $\mathrm{N}_{2}$ with mannose as carbon source were a few large clusters of $\mathrm{Y}$-cells observed among the filaments.

Mannose was also the only sugar on which Mycotypha africana produced budding cells under $\mathrm{CO}_{2}$ (Table 2). In view of the involvement of mannose in the formation of the yeast cell wall (Bartnicki-García \& Nickerson, I962 $a$; Bartnicki-García, I968 $b$; Falcone \& Nickerson, 1956; Marks, Keller \& Guarino, I97I), preliminary analyses of the Y-phase of $M$. africana were made but failed to reveal the presence of this sugar. Clearly there is scope for further work to establish the biochemical basis of dimorphism in the genus Mycotypha.

We thank Dr T. W. K. Young for the strains of Mycotypha microspora and Dr Altan Günalp for providing facilities at Hacettepe University. 


\section{REFERENCES}

Bartnicki-García, S. (1968a). Cell wall chemistry, morphogenesis and taxonomy of fungi. Annual Review of Microbiology 22, 87-108.

BartNICKI-García, S. (1968b). Control of dimorphism in Mucor by hexoses: inhibition of hyphal morphogenesis. Journal of Bacteriology 96, i 586-1 594.

Bartnicki-García, S. \& LipmanN, E. (1969). Fungal morphogenesis: Cell wall construction in Mucor rouxii. Science, Washington $\mathbf{1 6 5}, 302-304$.

Bartnicki-García, S. \& LipmanN, E. (I972). Inhibition of Mucor rouxii by polyoxin D: Effects of chitin synthetase and morphological development. Journal of General Microbiology 71, 30I-309.

Bartnicki-García, S. \& Nickerson, W. J. (1962a). Induction of yeast-like development in Mucor by carbon dioxide. Journal of Bacteriology 84, 829-840.

BartNicki-García, S. \& Nickerson, W. J. (1962 b). Nutrition, growth and morphogenesis of Mucor rouxii. Journal of Bacteriology 84, 84I-858.

BARTNICKi-García, S. \& NiCKERSON, W. J. (I962 c). Isolation, composition and structure of cell walls of filaments and yeast-like forms of Mucor rouxii. Biochimica et biophysica acta 58, I02-I 19.

ElswORTH, R. (1970). The measurement of oxygen absorption and carbon dioxide evolution in stirred deep cultures. In Methods in Microbiology, vol. 2, pp. 213-228. Edited by J. R. Norris and D. W. Ribbons. New York, London: Academic Press.

FALCONE, G. \& NiCKerson, W. J. (1956). Cell-wall mannan-protein of bakers yeast. Science, Washington r24, $272-273$.

FINN, R. K. (1954). Agitation-aeration in the laboratory and in industry. Bacteriological Reviews 18, $254-274$.

Lingappa, B. T., Prasad, M., Lingappa, Y., Hunt, D. F. \& Biemann, K. (1969). Phenethyl alcohol and tryptophol: autoantibiotics produced by the fungus Candida albicans. Science, Washington I63, 192-193.

Marks, D. B., Keller, B. J. \& GuARINo, A. J. (I97I). Growth of unicellular forms of the fungus Cordyceps militaris and analysis of the chemical composition of their walls. Journal of General Microbiology 69 , 253-259.

Romano, A. H. (1966). Dimorphism. In The Fungi, vol. 2, pp. 181-209. Edited by G. C. Ainsworth and A. S. Sussman. New York, London: Academic Press.

TerenzI, H. F. \& STORCK, R. (1968). Stimulation by phenethyl alcohol of aerobic fermentation in Mucor rouxii. Biochemical and Biophysical Research Communications 30, 447-452.

YounG, T. W. K. (1969). Electron and phase contrast microscopy of spores in two species of the genus Mycotypha (Mucorales). Journal of General Microbiology 55, 243-249. 